\title{
KAJIAN PENGgUNAAN DEBU LIMBAH TEMBAKAU DAN PEMBERIAN VERMIKOMPOS TERHADAP POPULASI DITYLENCHUS PADA BAWANG MERAH
}

\author{
Yanuar Mahir Hermawan ${ }^{1)}$, Subagiya ${ }^{2)}$, Ato Sulistyo ${ }^{2)}$ \\ 1) Mahasiswa S1 Program Studi Agroteknologi, Fakultas Pertanian, Universitas Sebelas Maret Surakarta \\ ${ }^{2)}$ Staf Dosen Program Studi Agroteknologi, Fakultas Pertanian, Universitas Sebelas Maret Surakarata \\ Kontak Penulis: Yanuarmahir97agrouns@gmail.com
}

\begin{abstract}
Shallot is a high value commodity for Indonesian people. The rate of shallot production is considered quite slow considering of the increasing population, income, and the area of shallot cultivation. On the cultivation of shallots common obstacle of Ditylenchus that cause damage to the stems and shallot bulb. The dust of tobacco and vermicompost waste is known to suppress the development of nematodes. This study aims to examine the use of tobacco ash waste and vermicompost on the population of Ditylenchus nematodes as well as the growth and yield of shallot. This research was conducted at Faculty of Agriculture, Sebelas Maret University (UNS) Surakata in August to December 2016. The study was performed using Completely Randomized Design (CRD) with treatments in the form of tobacco dust, vermicompost, combined tobacco dust and vermicompost and control treatment. Data were analyzed using variance test ( $F$ test) with $5 \%$ level. If the result shows significant effect then followed by DMRT of $5 \%$ level. The result of this research showed that the use of combination of tobacco ash waste and vermicompost could decrease nematode ditylenchus population in the soil. The use of tobacco ash waste could decrease total of parasite nematode population on plant tissue. The treatment didn't give any effect to shallot's yield. Shallot's yield was not influenced by the existence of nematode ditylenchus and another on plant tissue.
\end{abstract}

Keywords: Nematode, Parasitic, Nicotine, Non Parasitic

AGROTECHNOLOGY RESEARCH JOURNAL

Hermawan YM, Subagya, Sulistyo A. 2017. Study of Tobacco Ash Waste And Vermicompos Application on Ditylenchus Population on Shallot. Agrotech Res J 1(2):39-44.

Hermawan YM, Subagya, Sulistyo A. 2017. Kajian Penggunaan Debu Limbah Tembakau Dan Pemberian Vermikompos Terhadap Populasi Ditylenchus Pada Bawang Merah. Agrotech Res J 1(2):39-44.

\section{PENDAHULUAN}

Bawang merah merupakan salah satu jenis komoditas bernilai tinggi bagi masyarakat Indonesia, baik dilihat dari segi ekonomi maupun kandungan gizi. Bawang merah dapat dikonsumsi setiap hari sebagai bumbu dapur dan bahan pelengkap pangan. Produksi bawang merah di Provinsi Jawa Tengah tahun 2014 sebesar 519,356 ton, mengalami peningkatan sebesar $23,81 \%$ dibandingkan pada tahun 2013. Peningkatan produksi dinilai cukup lambat karena meningkatnya jumlah penduduk, pendapatan, dan luas panen bawang merah (BPS 2015). Puncak produksi bawang terjadi pada bulan-bulan tertentu, sementara konsumsi bawang merah hampir digunakan setiap hari dan bahkan pada hari besar keagamaan. Pembudidayaan bawang merah tentulah mengalami kendala dan gangguan. Gangguan yang terjadi salah satunya adanya serangan nematoda Ditylenchus. Kerusakan yang ditimbulkan terutama pada batang dan umbi bawang merah sehingga sangat merugikan.

Ditylenchus merupakan genus nematoda endoparasit yang memakan pada jaringan parenkim batang dan umbi, menyebabkan deformasi dan pembengkakan seperti cacar pada permukaan daun, pertumbuhan daun menjadi tidak teratur, dan merunduk layu lalu daun mati (Shurtleff et al 2000). Umbi yang terinfeksi akan membengkak dan membusuk selama

${ }^{*}$ Fak. Pertanian UNS Surakarta

JI.Ir. Sutami 36 A Surakarta penyimpanan bahkan umbi salah bentuk (terpelintir)(Abawi dan moktan 2013). Jenis nematoda yang menyerang tanaman bawang merah adalah Ditylenchus dipsaci.

Pengendalian $D$. dipsaci yang dilakukan dengan penggunaan bahan kimia yang diaplikasikan setiap 2-3 hari sekali oleh petani. Perlu adanya cara pengendalian nematoda yang tidak menimbulkan kerusakan lingkungan. Cara yang dapat dilakukan adalah dengan memanfaatkan debu limbah tembakau dan vermikompos.

Bahan aktif debu limbah tembakau yang berperan sebagai nematisida adalah nikotin. Unsur lain yang terkandung pada debu limbah tembakau adalah karbon organik $50,97 \%$, nitrogen total $1,83 \%$, fosfor $0,41 \%$, dan kalium 1,89\% (Talkah 2009). Vermikompos telah digunakan sebagai pengendali nematoda karena diduga terdapat nematoda non parasit yang dapat menekan perkembangan nematoda parasit termasuk $D$. dipsaci(Arancon dkk 2007). Penelitian bertujuan untuk mengkaji pengaruh penggunaan debu limbah tembakau dan vermikompos terhadap populasi nematoda Ditylenchus serta pertumbuhan dan hasil bawang merah. Penelitian ini bermanfaat sebagai alternatif bagi para petani bawang merah untuk dapat memanfaatkan debu limbah tembakau yang tidak dimanfaatkan lagi oleh pabrik rokok dan pemupukan vermikompos menjadi pengendali nematoda Ditylenchus sehingga dapat meningkatkan hasil bawang merah. 


\section{BAHAN DAN METODE}

Penelitian telah dilaksanakan di Fakultas Pertanian, Universitas Sebelas Maret Surakarta dengan ketinggian tempat $89 \mathrm{~m}$ dpl selama bulan Agustus sampai dengan bulan Desember 2016. Bahan yang digunakan adalah tanah bekas budidaya bawang merah yang berasal dari Tawangmangu, bibit bawang merah varietas Bima Brebes, tanah kaulin, serta debu limbah tembakau. Alat yang digunakan adalah cangkul, timbangan, papan nama, centrifuge, centrifuge tube, saringan nematoda, kamera, alat tulis, penggaris,pot plastik, dan logbook penelitian.

Rancangan penelitian menggunakan metode Rancangan Acak Lengkap (RAL) dengan faktor berupa PO: Kontrol tanpa pupuk, P1: Debu limbah tembakau, P2: Vermikompos, P3: Debu limbah tembakau dan vermikompos. Penentuan dosis didasarkan pada informasi dari petani yang biasa melakukan aplikasi debu limbah tembakau dengan dosis $100 \mathrm{~kg}^{-1}$ ha dan vermikompos 100 ton $^{-1}$ ha kemudian dikonversikan berdasarkan luas permukaan pot berdiamter $30 \mathrm{~cm}$ dengan berat tanah $10 \mathrm{~kg}^{-1}$ pot. Bawang merah ditanam dengan jarak tanam $12 \mathrm{~cm}$ dan diulang sebanyak 6 kali. Pelaksanaan penelitian meliputi .persiapan, pengamatan populasi dan identifikasi nematoda saat sebelum tanam, penanaman, aplikasi debu limbah tembakau dan vermikompos, pemeliharaan, pengamatan populasi nematoda pertengahan umur tanam, pengamatan pertumbuhan bawang merah, pengamatan populasi nematoda saat panen, panen. Variabel yang diamati berupa populasi nematoda di tanah, populasi nematoda di daerah perakaran, tinggi tanaman, jumlah anakan, jumlah daun, panjang daun, dan berat segar umbi. Data hasil pengamatan berupa populasi nematoda di tanah dan daerah perakaran, komponen pertumbuhan, serta berat hasil tanaman. Data selisih populasi awal dengan populasi akhir populasi nematoda dimultakkan kemudian dianalisis dengan uji $\mathrm{F}$ taraf $5 \%$ dilanjutkan dengan uji DMRT taraf $5 \%$ jika berbeda nyata.

\section{HASIL DAN PEMBAHASAN}

\section{Kondisi umum}

Penelitian ini dilaksanakan di rumah kasa yang terletak di belakang Gedung D, Fakultas Pertanian, Universitas Sebelas Maret Surakarta dengan ketinggian tempat $89 \mathrm{~m}$ dpl dilaksanakan dari bulan Agustus hingga bulan Desember 2016. Penelitian ini dilakukan dengan menggunakan tanah yang berasal dari pertanaman bawang merah dari Tawangmangu yang kemudian dijadikan sebagai media tanam. Penanaman dilakukan dengan menggunakan 12 pot yang terisi 2 tanaman per pot yang kemudian ditempatkan didalam rumah kasa untuk menghindari gangguan dari Organisme Pengganggu Tanaman (OPT). Suhu rumah kasa mencapai $27-29^{\circ} \mathrm{C}$, intensitas cahaya sebanyak $90 \%$ dikarenakan ada naungan berupa pohon di atas rumah kasa.

\section{Populasi nematoda di tanah}

Selisih populasi di tanah diperoleh dari perhitungan populasi awal dikurangi populasi akhir. Berdasarkan analisis yang dilakukan pada tabel 1 perlakuan yang diberikan tidak berpengaruh nyata terhadap populasi nematoda parasit maupun non parasit. Populasi nematoda pada perlakuan kontrol digunakan sebagai pembanding untuk menyatakan pengaruh terhadap penurunan populasi nematoda.

Tabel 1 Rata-rata selisih masing-masing populasi nematoda parasit dan non parasit di tanah

\begin{tabular}{lcc}
\hline \multicolumn{1}{c}{ Pemupukan } & \multicolumn{2}{c}{ Rata-rata populasi awal - } \\
& \multicolumn{2}{c}{ populasi akhir } \\
& Parasit & Non parasit \\
\hline Tanpa pupuk & $23.83 \pm 15.08 \mathrm{a}$ & $13.83 \pm 6.18 \mathrm{a}$ \\
Debu limbah tembakau & $22.00 \pm 9.47 \mathrm{a}$ & $7.17 \pm 5.19 \mathrm{a}$ \\
Vermikompos & $26.17 \pm 15,75 \mathrm{a}$ & $7.67 \pm 5,48 \mathrm{a}$ \\
Debu limbah tembakau dan vermikompos & $18.00 \pm 8.56 \mathrm{a}$ & $8.67 \pm 5,32 \mathrm{a}$ \\
\hline
\end{tabular}

Keterangan : Angka yang diikuti huruf yang sama dalam satu kolom tidak berbeda nyata pada DMRT taraf $5 \%$

Hasil pada perlakuan debu limbah debu limbah tembakau, vermikompos, serta kombinasi debu limbah tembakau dan vermikompos tidak berpengaruh nyata terhadap pertumbuhan populasi nematoda parasit maupun non parasit di tanah. Hal tersebut dikarenakan data tidak jauh beda terhadap perlakuan kontrol. Pemberian tembakau pada perlakuan debu limbah tembakau dan Kombinasi debu limbah tembakau dan verkikompos menunjukan penurunan rata-rata populasi nematoda parasit dan non parasit di tanah dibawah kontrol, diketahui selisih rata-rata populasi nematoda parasit dan non parasit dibandingkan dengan kontrol sebesar 1,83 ekor $^{-1} 100$ gram tanah dan 6.67 ekor $^{-1} 100$ gram tanah pada debu limbah tembakau serta 5.83 ekor $^{-1} 100$ gram tanah dan 5.17 ekor $^{-1} 100$ gram tanah pada kombinasi debu limbah tembakau dan vermikompos.

Genus nematoda yang ditemukan selama penelitian meliputi Ditylenchus, Meloidogyne, Helicotylenchus, Rotylenchus, Pratylenchus. Keberagaman nematoda yang ditemukan disebabkan karena tanah yang digunakan tidak disterilkan, sehingga keberadaan nematoda selain genus Ditylenchus dianggap wajar. Hasil identifikasi nematoda yang ditemukan menunjukkan berbagai stadia pertumbuhan yaitu juvenil hingga pradewasa.

Tabel 2 Rata-rata selisih masing-masing populasi nematoda parasit Ditylenchus dan non parasit di tanah

\begin{tabular}{llr}
\multicolumn{1}{c}{ Pemupukan } & \multicolumn{2}{c}{ Rata-rata populasi awal - populasi akhir } \\
& Ditylenchus & Non parasit \\
\hline Tanpa pupuk & $8.83 \pm 5.00 \mathrm{~b}$ & $13.83 \pm 6.18 \mathrm{a}$ \\
Debu limbah tembakau & $5.00 \pm 4,29 \mathrm{a}$ & $7.17 \pm 5.19 \mathrm{a}$ \\
Vermikompos & $3.33 \pm 3.88 \mathrm{a}$ & $7.67 \pm 5,48 \mathrm{a}$ \\
Debu limbah tembakau dan vermikompos & $1.67 \pm 1.21 \mathrm{a}$ & $8.67 \pm 5,32 \mathrm{a}$ \\
\hline
\end{tabular}

Keterangan : Angka yang diikuti huruf yang sama dalam satu kolom tidak berbeda nyata pada DMRT taraf $5 \%$ 
Hasil sidik ragam pada tabel 1.2 menyatakan bahwa pemberian perlakuan yang diberikan berpengaruh nyata terhadap populasi Ditylenchus di tanah. Perlakuan debu limbah tembakau, vermikompos serta kombinasi debu limbah tembakau dan vermikompos menunjukan penuruan perkembangan populasi nematoda Ditylenchus dibandingkan dengan kontrol.

Perlakuan kombinasi debu limbah dan vermikompos menunjukkan populasi yang lebih rendah dibandingkan dengan perlakuan lainnya, sehingga dapat disimpulkan perlakuan kombinasi debu limbah tembakau dan vermikompos dapat menekan perkembangan nematoda parasit ditylenchus dibandingkan perlakuan debu limbah tembakau dan vermikompos dengan selisih rata-rata penurunan secara berturut-turut debu limbah tembakau sebesar 3.83 ekor $^{-1} 100$ gram tanah, vermikompos sebesar 5.50 ekor $^{-1} 100$ gram tanah, serta debu limbah tembakau dan vermikompos sebesar 7.17 ekor $^{-1} 100$ gram tanah.

Perlakuan debu limbah tembakau mengalami penuruan disebabkan kandungan berupa nikotin yang bersifat sebagai nematisida (Qing dan John 2008). Perlakuan vermikompos juga menunjukan respon penurunan terhadap populasi nematoda Ditylenchus. Menurut (Rekhina 2012) Kejadian tersebut dapat dimungkinkan karena pemberian perlakuan vermikompos dapat menambah keberagaman jenis mikroorganisme di tanah. Menurut Arancon(2002) keberagaman jenis mikroorganisme akan berpengaruh baik langsung maupun tidak langsung terhadap perkembangan nematoda parasit maupun non parasit.

Perkembangan nematoda parasit selain Ditylenchus dapat mengakibatkan persaingan terhadap tanaman inang dan populasi nematoda non parasit yang lebih tinggi dibandingkan Ditylenchus memiliki kemungkinan terdapatnya nematoda predator (antagonisme) yang dapat memangsa nematoda lain sehingga dapat menekan dan menciptakan kondisi yang tidak menguntungkan untuk nematoda Ditylenchus. Hal tersebut sejalan dengan pendapat Wiratno et al (2013) yang menyatakan bahwa kondisi lingkungan dapat menurunkan populasi nematoda melalui persaingan dan antagonisme antara nematoda parasit dan non parasit.

\section{Populasi nematoda di jaringan tanaman}

Selisih populasi di jaringan tanaman diperoleh dari perhitungan populasi jaringan bawang merah saat pertengahan umur tanam sebagai populasi awal dikurangi populasi jaringan bawang merah saat panen sebagai populasi akhir. Hasil sidik ragam yang telah dilakukan pada data tabel 3 diketahui bahwa perlakuan yang diberikan berpengaruh nyata terhadap populasi nematoda parasit di jaringan tanaman.

Tabel 3 Rata-rata selisih populasi nematoda parasit di jaringan tanaman

\begin{tabular}{lc}
\hline \multicolumn{1}{c}{ Pemupukan } & $\begin{array}{c}\text { Rata-rata populasi awal - populasi } \\
\text { akhir }\end{array}$ \\
\hline Tanpa pupuk & $61.17 \pm 7.86 \mathrm{~b}$ \\
Debu limbah tembakau & $39.00 \pm 22.51 \mathrm{a}$ \\
Vermikompos & $68.67 \pm 13.95 \mathrm{~b}$ \\
Debu limbah tembakau dan vermikompos & $64.83 \pm 12.72 \mathrm{~b}$ \\
\hline
\end{tabular}

Keterangan : Angka yang diikuti huruf yang sama dalam satu kolom tidak berbeda nyata pada DMRT taraf 5\%

Hasil uji lanjut diketahui bahwa perlakuan debu limbah tembakau (debu limbah tembakau) berpengaruh nyata dalam menekan perkembangan populasi nematoda parasit di jaringan tanaman. Perlakuan debu limbah tembakau menunjukan nilai yang paling rendah dibandingkan kontrol dan perlakuan lain. Tabel 3 menunjukan perbandingan selisih rata-rata populasi nematoda parasit pada jaringan tanaman dalam bentuk histogram. Nematoda parasit pada perlakuan pemberian debu limbah tembakau memiliki selisih sebesar 22.17 ekor $^{-1}$ sampel akar lebih rendah dibandingkan dengan kontrol. Perlakuan vermikompos serta kombinasi debu limbah tembakau dan vermikompos menunjukan besar selisih rata-rata populasi nematoda parasit yang lebih tinggi dibandingkan kontrol sebesar 7.5 ekor $^{-1} 100$ sampel akar dan 3.66 ekor $^{-1}$ sampel akar. Kandungan nikotin pada perlakuan debu limbah tembakau (debu limbah tembakau) mempengaruhi populasi nematoda parasit yang terdapat di jaringan tanaman, sehingga dapat disimpulkan bahwa nikotin selain mengendalikan nematoda sebagai racun kontak juga mampu bekerja sebagai racun sistemik. Pendapat tersebut didukung oleh pernyataan Hadikusumo (2007) yang menyatakan pemberian nikotin ke suatu tanaman berarti telah memasukkan racun bagi hama ke dalam tubuh tanaman sehingga hama akan teracuni bila memakan tanaman tersebut.

Pemberian vermikompos pada perlakuan vermikompos dan kombinasi debu limbah tembakau dan vermikompos menunjukan peningkatan rata-rata populasi nematoda parasit di jaringan tanaman. Hal tersebut dimungkinkan karena kandungan bahan organik dan mikroorganisme yang kompleks di vermikompos menyebabkan pertumbuhan nematoda di tanah meningkat yang secara tidak langsung mempengaruhi peningkatan total nematoda pada tanah di pertanaman bawang merah. Peningkatan tersebut berkontribusi secara langsung terhadap peningkatan nematoda parasit yang menginfeksi jaringan bawang merah sehingga menyebabkan jumlah nematoda parasit yang ditemukan lebih tinggi dibandingkan dengan kontrol pada pemberian vermikompos pada perlakuan vermikompos maupun kombinasi pemupukan.

Berdasarakan analisis sidik ragam pada data tabel 3 diketahui bahwa perlakuan yang diberikan tidak berpengaruh nyata terhadap populasi nematoda Ditylenchus. Nematoda Ditylenchus tidak menunjukkan respon terhadap perlakuan yang diberikan. Kejadian tersebut dimungkinkan, menurut pendapat Wharton (2004) setiap spesies mempunyai kondisi lingkungan optimum yang berbeda untuk perkembangan dan aktivitas metabolismenya. Perkembangan nematoda yang dipengaruhi lingkungan memungkinkan munculnya nematoda dominan sehingga disimpulkan bahwa jumlah populasi nematoda Ditylenchus dipengaruhi adanya nematoda dominan yang dapat 
menimbulkan persaingan inang di jaringan tanaman(Robinson et al 1987).

Tabel 4 Rata-rata selisih populasi nematoda parasit Ditylenchus di jaringan tanaman

\begin{tabular}{|c|c|}
\hline Pemupukan & $\begin{array}{c}\text { Rata-rata populasi awal - populas } \\
\text { akhir }\end{array}$ \\
\hline Tanpa pupuk & $2.17 \pm 0.4082 a$ \\
\hline Debu limbah tembakau & $1.67 \pm 0.8165 a$ \\
\hline Vermikompos & $2.33 \pm 0.8165 a$ \\
\hline Debu limbah tembakau dan vermikompos & $2.00 \pm 0 \mathrm{a}$ \\
\hline
\end{tabular}

Keterangan : Angka yang diikuti huruf yang sama dalam satu kolom tidak berbeda nyata pada DMRT taraf $5 \%$

\section{Pertumbuhan dan hasil bawang merah}

\section{Tinggi tanaman}

Berdasarkan Analisis sidik ragam yang telah dilakukan terhadap data yang tersaji pada Tabel 5 diketahui bahwa tidak ada perlakuan yang berpengaruh nyata terhadap tinggi tanaman bawang merah. Hal ini dikarenakan hasil pengukuran tinggi tanaman yang tidak terlalu jauh berbeda.

Tabel 5 Rata-rata tinggi tanaman bawang merah

\begin{tabular}{lrrrrrrr}
\hline \multirow{2}{*}{ Pemupukan } & \multicolumn{7}{c}{ Ningou } \\
\cline { 2 - 8 } & 25 & 3 & 4 & 5 & 6 & 7 & 8 \\
\hline Tanpa pupuk & 23.67 & 35.33 & 36.67 & 35.25 & 35.25 & 37.58 & 35.88 \\
Debul limban tembakau & 23.08 & 34.83 & 36 & 35.42 & 35.83 & 38 & 36 \\
Vermikompos & 25.17 & 35.17 & 39.92 & 38.75 & 37.88 & 34.5 & 33.5 \\
Debul limbah tembakau dan vermikompos & 23.17 & 33.25 & 34 & 36.42 & 37.33 & 37.42 & 35.5 \\
\hline
\end{tabular}

\section{Jumlah anakan}

Berdasarkan analisis sidik ragam yang dilakukan terhadap data yang tersaji pada Tabel 6 dapat diketahui bahwa perlakuan yang diberikan tidak berpengaruh nyata terhadap jumlah anakan bawang merah karena data menunjukkan rata-rata penambahan anakan bawang merah tidak jauh beda pada setiap perlakuan.

Tabel 6 Rata-rata jumlah anakan bawang merah

\begin{tabular}{lrrrrrrr}
\hline \multirow{2}{*}{ Pemupukan } & \multicolumn{8}{c}{ Minggu } \\
\cline { 2 - 8 } & 2 & 3 & 4 & 5 & 6 & 7 & 8 \\
\hline Tanpa pupuk & 3.83 & 4.67 & 6.33 & 6.67 & 6.83 & 7 & 7.2 \\
Debu limbah tembakau & 3.83 & 5.33 & 6 & 8 & 8.33 & 7.67 & 7.83 \\
Vermikompos & 3.5 & 5.5 & 6.5 & 8.5 & 6.5 & 8.33 & 9.25 \\
Debu limbah tembakau dan vermikompos & 3.67 & 3.83 & 5.33 & 5.67 & 7.67 & 6.83 & 5.83 \\
\hline
\end{tabular}

\section{Jumlah daun}

Berdasarkan analisis sidik ragam yang telah dilakukan terhadap data yang tersaji pada tabel 7 diketahui bahwa semua perlakuan yang diberikan tidak berpengaruh nyata terhadap jumlah daun bawang merah. Perlakuan debu limbah tembakau menunjukan nilai rata-rata jumlah daun tertinggi pada minggu ke 6 sebesar 23.50 helai, pada perlakuan vermikompos menunjukan nilai rata-rata tertinggi pada minggu ke 5 sebesar 23.33 helai serta pada perlakuan kombinasi debu limbah tembakau dan vermikompos mencapai rata-rata jumlah daun tertinggi pada minggu ke 6 sebanyak 25.17 helai
Tabel 7 Rata-rata jumlah daun bawang merah

\begin{tabular}{lrrrrrrr}
\hline & \multicolumn{7}{c}{ Mingou } \\
\cline { 2 - 8 } & 2 & 3 & 4 & 5 & 6 & 7 & 8 \\
\hline Tanpa pupuk & 12.5 & 16.17 & 17.67 & 19 & 21.67 & 18.17 & 10.4 \\
Debul limbah tembakau & 14.33 & 16.67 & 20.33 & 21.33 & 23.5 & 22.5 & 13 \\
Vermikompos & 13.5 & 19.5 & 21.83 & 23.33 & 16.83 & 19.33 & 14 \\
Debul limbah tembakau dan vermikompos & 10.33 & 15 & 15.83 & 16.67 & 25.17 & 17.5 & 11.33 \\
\hline
\end{tabular}

\section{Panjang daun}

Berdasarkan hasil analisis sidik ragam yang telah dilakukan terhadap data tabel 8 diketahui bahwa semua perlakuan tidak berpengaruh nyata terhadap pertambahan panjang daun bawang merah. Hal ini disebabkan data panjang daun hampir sama pada setiap perlakuan.

Tabel 8 Rata-rata panjang daun bawang merah

\begin{tabular}{lrrrrrrr}
\hline & \multicolumn{8}{c}{ Memupukan } & 2 & 3 & 4 & 5 & 6 & 7 & 8 \\
\cline { 2 - 8 } \multicolumn{1}{c}{} & 23.33 & 33 & 33.25 & 31.75 & 32.08 & 34.42 & 32.38 \\
\hline Tanpa pupuk & 21.5 & 32.58 & 33.5 & 32.33 & 32.25 & 34.42 & 32.42 \\
Debul limbah tembakau & 23.25 & 33.25 & 37.33 & 35.5 & 34.55 & 31.17 & 30 \\
Vermikompos & 21.33 & 30.75 & 31.83 & 32.58 & 34.08 & 34.17 & 32.25 \\
Debu limbah tembakau dan vermikompos
\end{tabular}

\section{Berat segar bawang merah}

Tanaman bawang merah dipanen pada umur 7 MST tepatnya pada hari ke-50 setelah tanam. Tanaman dapat dipanen setelah daun yang sudah mulai rebah mencapai $60-70 \%$. Sampel bawang merah yang telah dipanen kemudian ditimbang menggunakan timbangan dan menghasilkan data yang disajikan pada Tabel 9 .

Tabel 9 Rata-rata berat segar bawang merah

\begin{tabular}{lc}
\hline \multicolumn{1}{c}{ Pemupukan } & Berat segar $(\mathrm{g})$ \\
\hline Tanpa pupuk & $2.20 \pm 0.99 \mathrm{~b}$ \\
Debu limbah tembakau & $1.78 \pm 0.57 \mathrm{ab}$ \\
Vermikompos & $2.41 \pm 1.51 \mathrm{~b}$ \\
Debu limbah tembakau dan vermikompos & $1.01 \pm 0.47 \mathrm{a}$ \\
\hline
\end{tabular}

Keterangan : Angka yang diikuti huruf yang sama dalam satu kolom tidak berbeda nyata pada DMRT taraf $5 \%$

Perbandingan perlakuan kontrol tanpa pupuk antara populasi dltylenchus di jaringan tanaman dengan berat segar umbi bawang merah menunjukkan data bahwa populasi ditylenchus tidak mempengaruhi hasil bawang merah. Hal tersebut didukung oleh data pada perlakuan debu limbah tembakau, vermikompos, Kombinasi pemupukan menunjukkan hal yang serupa dimana ketika populasi nematoda ditylenchus diatas kontrol , berat segar umbi bawang merah juga diatas kontrol pada perlakuan vermikompos. Sedangkan pada perlakuan debu limbah tembakau dan kombinasi pemupukan menunjukkan populasi nematoda ditylenchus di bawah kontrol namun berat segar umbi juga dibawah kontrol yang seharusnya jika populasi berkurang maka hasil panen lebih tinggi dibandingkan dengan kontrol. Sehingga dapat disimpulkan bahwa hasil berat segar umbi tanaman bawang merah tidak 
dipengaruhi oleh keberadaan nematoda ditylenchus di jaringan tanaman. Kejadian tersebut diduga karena jumlah nematoda ditylenchus di jaringan tanaman belum mampu menyebabkan kerusakan pada umbi bawang merah, didukung oleh pernyataan Pangeso $\mathrm{J}$ (2010) yang menyatakan bahwa nematoda memiliki kerapatan tertentu untuk mampu menyebabkan kerusakan atau kerugian pada tanaman inang.

Selama pengamatan diketahui bahwa pertumbuhan tanaman terlihat normal namun terdapat sampel tanaman yang menunjukan pembentukan umbi yang terhambat. Terhambatnya perkembangan umbi terlihat saat memasuki fase generatif, beberapa sampel menunjukan perkembangan umbi yang tetap setiap minggunya dan terdapat sampel yang mati sebelum panen. Gambar 1 menunjukkan keadaan umbi bawang merah yang mengalami kegagalan pembentukan umbi.

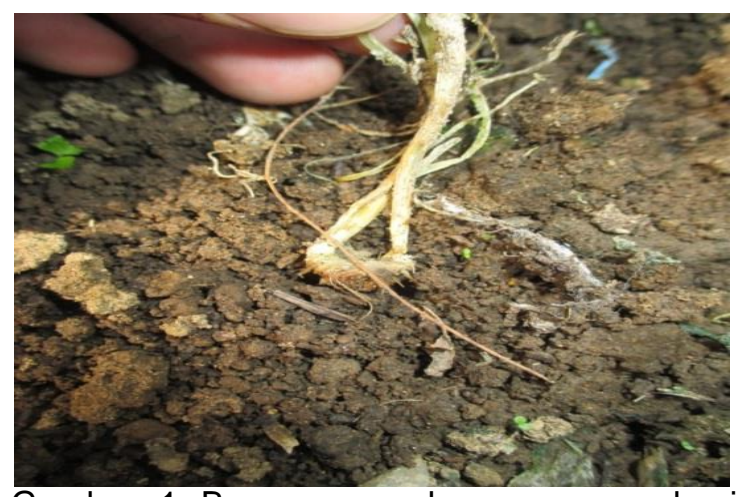

Gambar 1 Bawang merah yang mengalami kegagalan pembentukan umbi

Kandungan arsen pada debu limbah tembakau diduga menyebabkan tanaman bawang merah mengalami penghambatan pertumbuhan saat memasuki fase generatif. Kejadian tersebut sesuai dengan data berat segar umbi bawang merah pada pemberian perlakuan debu limbah tembakau pada pemupukan debu limbah tembakau dan kombinasi pemupukan yang menunjukkan data hasil berat segar bawang merah dibawah kontrol. Menurut pendapat Jiménez, Esteban dan Peñalosa (2012) menyatakan bahwa pemberian debu limbah tembakau pada tanaman terlalu banyak dapat menyebabkan keracunan tanaman yang ditandai dengan hambatan pertumbuhan, degradiasi klorofil, deplesi hara, dan cekaman oksidatif karena debu limbah tembakau mengandung arsen. Debu limbah tembakau yang digunakan merupakan limbah mentah dari sisa produksi rokok. Dalam penelitian Talkah A (2010) telah membuktikan bahwa debu limbah tembakau mengandung arsen yang tidak memenuhi standart sehingga penggunaan debu limbah tembakau perlu divermikomposkan menggunakan cacing tanah dengan tujuan menurunkan kandungan arsen. ( Namun dalam penelitian ini, debu limbah tembakau tidak melalui tahap pengomposan dengan bantuan cacing (vermikompos), sehingga kandungan arsen diduga masih tinggi sehingga menjadi penyebab terhambatnya pertumbuhan pada tanaman bawang merah terkhusus pada hasil berat segar bawang merah.

\section{KESIMPULAN DAN SARAN}

\section{Kesimpulan}

Kesimpulan yang diperoleh berdasarkan penelitian ini antara lain sebagai berikut:

1. Penggunaan kombinasi debu limbah tembakau dan vermikompos mampu menurunkan populasi nematoda ditylenchus di tanah

2. Penggunaan debu limbah tembakau mampu menurunkan total populasi nematoda parasit di jaringan tanaman.

3. Perlakuan tidak berpengaruh terhadap berat segar bawang merah.

4. Berat segar umbi bawang merah tidak dipengaruhi oleh keberadan nematoda ditylenchus dan nematoda lain di jaringan tanaman.

\section{Saran}

Saran yang dapat diberikan berdasarkan penelitian ini yaitu:

1. Perlu dilakukan penelitian lanjut dengan menggunakan variasi dosis pada debu limbah tembakau dan vermikompos untuk mengetahui dosis yang paling baik dalam menurunkan populasi nematoda Ditylenchus.

2. Perlu dilakukan sterilisasi tanah untuk mengetahui lebih lanjut dampak perlakuan debu limbah tembakau dan vermikompos agar lebih mengetahui pengaruh terhadap nematoda Ditylenchus.

\section{DAFTAR PUSTAKA}

Abawi GS, Moktan K. 2013. Bloat nematode: a reemerging and damaging pest of garlic and other hosts. Proceedings of the Mid-Atlantic Fruit and Vegetable Convention, Hershey, PA. 29-31 Januari, 2013. Debu limbah tembakau68-170.

Arancon NQ, Edward CA, Dick $R$, and Dick Linda. 2007. Vermikompost tea production and plant grownth impacts. Biocyle. 1(1):1-2.

Arancon NQ, Edward CA, Lee SS. 2002. Management of plant parasitic nematode population by use of vermicompost. The Ohio State University, 1735 Neil Avenue, Columbus, $\mathrm{OH} 43210$ USA

BPS [Badan Pusat Statistik]. 2015. Produksi cabai besar, cabai rawit, dan bawang merah tahun 2014 provinsi jawa tengah.

Hadikusumo SA. 2007. Pengaruh ekstrak tembakau terhadap serangan rayap kayu kering Cryptotermes cynocephalus Light. pada bambu apus (Gigantochloa apus Kurz). J IImu Kehutanan. $1(02): 47-54$.

Jimenez EM, Esteban E, dan Penalosa JM. 2012. The fate in soil-plant systems. Reviews of Environmental Contamination and Toxicology 215: 1-27. DOI: 10.1007/978-1-4614-1463-6_1.

Marwoto B. 2009. Pengujian kisaran inang nematoda bentuk ginjal (Rotylenchus reniformis linford dan oliveira). J HOrt. 19(4):442-449.

Qing $Y$ dan John WP. 2008. Selective nematicidal activitiy of nicotine. $\mathrm{J}$ food, agriculture and envitonment (JFAF), Juni 2008: 428-432. ISSN: 1459-0263 
Rekhina 0 2012. Pengaruh pemberian vermikompos dan kompos daun serta kombinasinya terhadap pertumbuhan dan produksi tanaman sawi (Barssica juncea 'Toksakan'). Departemen biologi. Fakultas matematika dan ilmu pengetahuan alam. Universitas negeri Yogyakarta

Robinson A.F, R.N. Inserra, E.P. Caswell-Chen, N. Vovlas, and A. Troccoli. 1997. rotylenchulus species: identification, distribution, host ranges, and crop plant resistance. nematropica. 27:127-180.

Shurtleff. Malcolm CA. dan Charles W. 2000. Diagnosing plant diseases caused by nematodes. American Phytopathological Society. APS Press. DOI: 10.1046/j.1439-0434.2001.0596c.x

Talkah A 2009. Pengaruh pupuk organik vermikompos limbah jengkok tembakau pabrik rokok terhadap produktivitas budidaya tanaman melon (Cucumis melo L) varietas red aroma. J Cendekia. 7:3-5 EISSN: 1693-6094.

Wharton DA. 2004. Survival strategies. Pp. 371-399 In: Gaugler R \& Anwar LB, eds. Nematode Behaviour. CABI, New Jersey, USA.

Wiratno. Siwanto. dan Trisawa IM. 2013. Prosepek ekstrak daun tembakau sebagai nematisida nabati. BPTP Sumatera selatan. Buletin tanaman tembakau, serat \& minyak industri. 5(2):91-9. ISSN: 2085-6717. 